\title{
NEW STRUCTURAL ECONOMICS \\ - DISCUSSION ABOUT DEVELOPMENT POLICY BASED ON INNOVATION
}

\author{
KATARZYNA SZARZEC ${ }^{4}$ \\ ${ }^{1}$ Poznan University of Economics and Business, POLAND \\ e-mail: marek.ratajczak@ue.poznan.pl \\ 2 University of Szczecin, POLAND \\ e-mail: izabela.bludnik@wzieu.pl \\ ${ }^{3}$ Poznan University of Economics and Business, POLAND \\ e-mail: dawid.piatek@ue.poznan.pl \\ ${ }^{4}$ Poznan University of Economics and Business, POLAND \\ e-mail: katarzyna.szarzec@ue.poznan.pl
}

MAREK RATAJCZAK, ${ }^{1}$ IZABELA BLUDNIK, ${ }^{2}$ DAWID PIĄTEK, ${ }^{3}$

\author{
RECEIVED \\ 23 November 2017 \\ ACCEPTED \\ 5 January 2018 \\ JEL \\ CLASSIFICATION \\ 011, 012, 038, 044
}

KEYWORDS

new structural economics, economic development, innovation, economic policy

ABSTRACT The ongoing discussion in Poland on the design, implementation and coordination of a sustainable development policy based on innovation refers to the research and achievements of co-creators and proponents of the New Structural Economics (NSE). This article presents both the strengths of the NSE research programme, which demonstrate its usefulness in the context of the situation and challenges that Poland is facing, as well as its fundamental weaknesses, which may have a negative impact on the quality of the debate on a long-term development, innovation and competitiveness policy. The NSE recommendations for the development policy should be treated as a starting point which still requires the consideration of many additional phenomena and processes taking place in the social, economic and political environment of a given economy.

\section{Introduction}

Poland is facing many challenges, including designing, implementing and coordinating a sustainable development policy. The importance of this matter has been emphasised in two documents presented by the Prime Minister Mateusz Morawiecki, namely Plan na rzecz odpowiedzialnego rozwoju (2016) and its continuation and operationalisation Strategia na rzecz Odpowiedzialnego Rozwoju do roku 2020 (2017). Both documents refer to the 
research and achievements of co-creators and proponents of the New Structural Economics (NSE), a framework which is frequently mentioned in the context of the discussion on innovation and reindustrialisation of the economy.

The NSE programme focuses on the real economy, strengthening of its industrial capacity, increasing innovation, improving the condition and quality of political and economic institutions. At the same time, however, the NSE programme is very general; it lacks unambiguous guidelines or practical solutions, which may have a negative impact on the quality of the ongoing debate on the policy of long-term development, innovation and competitiveness in Poland.

The main objective of this article is to demonstrate that the NSE recommendations for the development policy should be treated as a starting point which still requires the consideration of many additional phenomena and processes taking place in the social, economic and political environment of a given economy.

\section{Research programme of New Structural Economics}

The New Structural Economics is a new perspective on development economics proposed by Justin Y. Lin (2010), which the author calls Development Thinking 3.0. NSE combines a neoclassical approach with some elements of the so-called old structuralism. Economic development is considered as a process of continuous technological change, innovation and transformation of the economic structure. The leading figures of NSE include such authors as: Dani Rodrik (2003, 2009, 2010), Ricardo Hausmann and Andrés Velasco (Hausmann et al., 2008), Philippe Aghion (2009), Ann Harrison (2010, 2011, 2014), Célestin Monga (Lin, Monga, 2012, 2012b).

NSE is based on three ideas (Lin, 2010):

1. Economies at different stages of development vary in terms of the availability of production factors and structure (capital intensity of production, size of businesses, nature of risk, complexity of transactions). For an economy to work well, it is essential to have hard infrastructure (roads, bridges, energy networks, etc.) and soft infrastructure (informal and formal institutions), appropriate for the conditions at a given stage of development.

2. There are not just two but many stages of development. They form a broad spectrum: from the primitive agriculture-based economies with the lowest income, to the highly developed and industrialised economies with the highest income.

3. At every stage of development, the market is a mechanism which enables effective allocation of resources, while the ultimate driver of development is the private sector. Nevertheless, it must be supplemented with state actions promoting structural changes and technical progress. The state does not replace the market but actively supports and promotes industrial development and innovativeness of the economy.

The transition to a higher stage of development becomes possible when the availability of production factors changes, which requires that the structure of the economy be changed through innovation - not only are new techniques and production methods sought, but also products in which the economy has a comparative advantage are needed. Businesses that engage in this activity create knowledge (uncompetitive and non-exclusive), which is also used by other companies. These are positive externalities, extremely important for entrepreneurs who are starting manufacturing of new products exposed to a high risk of failure.

A prerequisite for ensuring development is the existence of a pricing system that provides information on the scarcity of resources. Based on this, private enterprises seeking to maximise profits will specialise in manufacturing 
products in which the economy has comparative advantages. It is important that the state promote competition and not distort the price signals coming from the market.

As a result, the tasks of the state include: (1) providing information on new manufacturing methods and products that are compatible with comparative advantages resulting from changes in production factors; (2) coordinating business investments and providing appropriate hard and soft infrastructure that facilitates business operations and reduces transaction costs; (3) subsidising activities characterised by positive externalities in the development process; (4) facilitating the development of new enterprises by creating favourable conditions for their development, attracting foreign direct investments that will increase know-how.

As far as industrial policy is concerned, Lin and Monga (2012a) propose the following action sequence for the government:

1. Identify countries experiencing fast economic growth with similar structure of production factors but with income per capita twice as high. Then, determine which sectors of the economy producing export goods have been developing in these countries over the last 20 years.

2. If private enterprises already operate in these sectors, identify the obstacles that may slow down their development or hinder the entry of new companies, and remove them.

3. If there are no domestic enterprises in these sectors, attempt to attract foreign direct investment from the countries identified in step one or support the development of private companies through business incubators, technology parks, etc.

4. Continuously monitor activities of private companies aimed at discovering new comparative advantages and, if identified, support the development of these sectors of the economy.

5. In the case of countries with poor infrastructure and an unfavourable environment for economic activity, introduce special economic zones in order to reduce entry barriers for private companies, attract foreign direct investments and facilitate the emergence of industrial clusters.

6. Provide tax incentives (for a specified period) for companies that are searching for sectors with a comparative advantage, co-finance their investments or facilitate access to foreign currencies.

\section{Evaluation of New Structural Economics research progragmme}

One of the considerable advantages of NSE is that, although it stresses the role of the market as an effective resource allocation mechanism, it nevertheless considers transaction costs, thus referring to the achievements of new institutional economics (Coase, 1960; Williamson, 1975; North, 1990). Additionally, it rightly emphasises that the discovery of comparative advantages requires state intervention due to uncertainty, externalities and the need to coordinate activities. Lin and Monga (2012b) point out that the use of NSE allows to explain stylised facts of economic growth in rapidly developing countries identified in The Growth Report (2008).

The weakness of NSE is undoubtedly its heterogeneity, which consists in combining very diverse elements attributed to competing schools and paradigms. This has a negative impact on its coherence on the methodological, theoretical and applicational levels. NSE is rather a set of, often loosely related, views that do not create a theoretical "hard core" that would be subject to a convincing empirical verification.

Furthermore, the recommendations regarding the active role of the state are nothing new. Although the importance of the market and the state is rightly emphasised, the question arises as to the practical recommendations of NSE regarding industrial policy. An active role can be recommended in theoretical models; 
however, practice requires an answer to the question of how can this be accomplished? As noted by Rodrik (2010), should recommendations not be preceded by a definitive diagnosis in all cases? NSE does not provide answers to these questions because this concept is very general and applicable to countries practically at all stages of development. Consequently, NSE instead of providing answers, raises further questions, e.g. What institutions and policies are appropriate for countries at various stages of development? How to make the market and the state play their roles to ensure an effective resource allocation and transition to a higher level of development?

Another matter is the ability to implement the NSE recommendations considering institutional constraints. Although Lin (2010) mentions institutional issues, they are left open for interpretation. On the other hand, institutional economics emphasises that it is the formal and informal institutions that may hinder economic development (North, 1990, 2005). While the state creates formal institutions, its influence on informal institutions is much smaller, and the change of informal institutions is slow.

Another weakness of NSE is the lack of reference to the interaction between political and economic institutions. As Acemoglu and Robinson (2012) argue, it is impossible to achieve a high level of development without pluralistic political and economic institutions. When a country has an undemocratic government who breaks the rule of law, it will set up exploitative economic institutions that do not facilitate economic growth but increase the wealth of those in charge instead.

\section{Conclusions}

The NSE recommendations might be applied to Poland in relation to the search for new comparative advantages. Based on the conclusions from NSE, proposals can be formulated as to the directions of public aid or the development of hard infrastructure. Nevertheless, NSE does not address many of the weaknesses which are a problem for the Polish economy and society, such as: weakness of institutions (formal ones created by the state as well as informal ones, including low social capital); situation on the labour market; condition of public finance; demographic problems; low innovation (Raport: Następne 25 lat..., 2015; Państwo i My..., 2015; Plan na rzecz odpowiedzialnego rozwoju, 2016; Strategia na rzecz Odpowiedzialnego Rozwoju do roku 2020, 2017; Wyzwania rozwojowe Polski..., 2016).

In the discussion which accompanies the policies considered in Plan na rzecz odpowiedzialnego rozwoju and its continuation and operationalisation Strategia na rzecz Odpowiedzialnego Rozwoju do roku 2020, it is emphasised that in both documents the conditions and threats to achieving what is intended were relatively poorly developed. In turn, the ability of the state to correctly define development goals and then select appropriate tools for implementation in terms of both allocation and regulation, as well as the effectiveness and efficiency of the activities of the state, were treated too optimistically.

One of the conditions and threats is undoubtedly the progressing financialisation (Ratajczak, 2012, 2017) of the economy. However, it should be noted that in the case of Poland at the current stage of development of the economic and financial sectors, threats are associated mostly with the transmission of the effects of events and phenomena taking place in the international environment rather than with the changes within the financial sector in the Polish economy. Nevertheless, given the continuous internationalisation of the Polish economy, even the phenomena which have, as of yet, a relatively weak impact in Poland considering the current structure of the economy, will gradually begin to play an increasingly important role. 


\section{References}

Acemoglu, D., Robinson, J. (2012). Why nations fail: the origins of power, prosperity, and poverty. New York: Crown Publishers.

Aghion, P. (2009). Some thoughts on industrial policy and growth. Working Paper, 2009-2009. Retrieved from: http://www.ofce. sciences-po.fr/pdf/dtravail/WP2009-09.pdf (15.02.2018).

Coase, R.H. (1960). The problem of social cost. Journal of Law and Economics, 3 (1), 1-44.

Wyzwania rozwojowe Polski. Czy Plan Morawieckiego może im zaradzić? (2016). Analiza Fundacji Kaleckiego, 01/2016. Retrieved from: http://www.pte.pl/pliki/2/12/WyzwaniarozwojowePolski.pdf (February 15, 2018).

Harrison, A., Rodríguez-Clare, A. (2010). Trade, foreign investment, and industrial policy for developing countries. In: D. Rodrik, M. Rosenzweig (eds.), Handbook of development economics, Vol. 5 (pp. 4039-4214). Amsterdam: North-Holland.

Harrison, A., Sepúlveda, C. (2011). Learning from developing country experience: Growth and economic thought before and after the 2008-2009 crisis. Comparative Economic Studies, 53 (3), 431-453.

Du, L., Harrison, A., Jefferson, G. (2014). FDI spillovers and industrial policy: The role of tariffs and tax holidays. World Development, 64 (C), 366-383.

Hausmann, R., Rodrik, D., Velasco, A. (2008), Growth diagnostics. In: N. Serra, J.E. Stiglitz (eds.), The Washington consensus reconsidered: Towards a new global governance (pp. 324-355). Oxford: Oxford University Press.

Lin, J.Y. (2010). New Structural Economics. A framework for rethinking development. Policy Research Working Paper, 5197, Washington: The World Bank. Retrieved from: https://openknowledge.worldbank.org/handle/10986/19919 (15.02.2018).

Lin, J.Y., Monga, C. (2012a). Growth identification and facilitation: The role of the state in the dynamics of structural change. In: J.Y. Lin (ed.), New Structural Economics. A framework for rethinking development and policy (pp. 141-180). Washington: The World Bank.

Lin, J.Y., Monga, C. (2012b). The Growth Report and New Structural Economics. In: J.Y. Lin (ed.), New Structural Economics. A framework for rethinking development and policy (pp. 81-112). Washington: The World Bank.

Raport: „Następne 25 lat. Jakie reformy musimy przeprowadzić, by dogonić Zachód?” (2015). Warszawa: Forum Obywatelskiego Rozwoju. Retrieved from: https://for.org.pl/pl/a/3559,Raport-Nastepne-25-lat-Jakie-reformy-musimy-przeprowadzic-bydogonic-Zachod (15.02.2018).

North, D.C. (1990). Institutions, institutional change and economic performance. Cambridge: Cambridge University Press.

North, D.C. (2005). Understanding the process of economic change. Princeton: Princeton University Press.

Państwo i My. Osiem grzechów głównych Rzeczypospolitej (2015). Kraków: Fundacja Gospodarki i Administracji Publicznej. Retrieved from: http://www.euroreg.uw.edu.pl/pl/publikacje,panstwo-i-my-osiem-grzechow-glownych-rzeczypospolitej (15.02.2018).

Plan na rzecz odpowiedzialnego rozwoju (2016). Annex to the resolution of the Council of Ministers no 14/2016 of 16 February 2016. Retrieved from: http://www.miir.gov.pl/media/16403/uchwala_plan_odp_rozw_16022016.pdf (15.02.2018) (in Polish).

Ratajczak, M. (2012). Finansyzacja gospodarki. Ekonomista, 3, 281-302.

Ratajczak, M. (2017). Finansjalizacja gospodarki: wymiary dyskusji. Bezpieczny Bank, 68 (3), 7-22.

Rodrik, D. (2003). Growth strategies. Centre for Economic Policy Research Discussion Paper, 4100. Retrieved from: https://papers.ssrn. com/sol3/papers.cfm?abstract_id=478320 (15.02.2018).

Rodrik, D. (2009). One economics, many recipes: Globalization, institutions, and economic growth. Princeton: Princeton University Press.

Rodrik, D. (2010). Diagnostics before prescription. Journal of Economic Perspectives, 24 (3), 33-44.

Strategia na rzecz Odpowiedzialnego Rozwoju do roku 2020 (z perspektywą do 2030 r.) (2017). Resolution of the Council of Ministers no 8 of 14 February 2017. Retrieved from: http://prawo.sejm.gov.pl/isap.nsf/download.xsp/WMP20170000260/O/M20170260.pdf (15.02.2018) (in Polish).

The Growth Report: Strategies for sustained growth and inclusive development (2008). Commission on Growth and Development Final Report. Washington: The World Bank. Retrieved from: https://openknowledge.worldbank.org/handle/10986/6507 (15.02.2018).

Williamson, O.E. (1975). Market and hierarchies: Analysis and anti-trust implications. A study in the economics of internal organization. New York: The Free Press.

Cite this article aS: Ratajczak, M., Bludnik, I., Piątek, D., Szarzec, K. (2018). New Structural Economics - discussion about development policy based on innovation. European Journal of Service Management, 1 (25), 237-241. DOI: 10.18276/ejsm.2018.25-29. 